\title{
Defining International Terrorism to Protect Human Rights in the Context of Counter-terrorism
}

\author{
Stella Margariti \\ University of Dundee; Managing Editor, Oxford Reports for International \\ Law, OUP \\ stllmrgrt@gmail.com
}

\begin{abstract}
The main argument of this article is that defining international terrorism will further the protection of human rights in the context of counter-terrorism. For this purpose, it will be shown that the transnational legal system under which counter-terrorism operates is fraught with problems regarding human rights protection. Secondly, it will be shown how domestic counter-terrorism legislation can become a breeding ground for serious human rights violations, when based on too broad or otherwise problematic definitions of terrorism. Finally, it will be explored how human rights protection has been addressed so far by the relevant bodies of the United Nations and to what extent, if finalised, an internationally agreed upon definition of terrorism in the framework of the UN Comprehensive Convention will contribute to a fuller enjoyment of rights in a counterterrorism context.
\end{abstract}

\section{Keywords}

terrorism - counter-terrorism - human rights - definition of terrorism - transnational law - domestic counter-terrorism legislation - United Nations

\section{1 \\ Introduction}

International terrorism does not need any introduction; it is a very well-known global scourge, having victimised countless individuals around the world, through numerous forms and with a variety of violent means. It is definitely a crime which demands an immediate response; every State can agree on this.

(C) STELLA MARGARITI, 2019 | DOI:10.1163/18750230-02901004

This is an open access article distributed under the terms of the prevailing CC-BY-NC license at the time of publication. 
What every State cannot agree on however is its definition. It is striking how a crime that has plagued so many countries, so many ethnic or religious groups, combatants or non-combatants, in armed conflict ${ }^{1}$ or in peacetime, cannot be put in a definitional context for the purpose of prosecuting it for what it is: an international crime. ${ }^{2}$

The answer to the question of why there is a need for an international definition of terrorism has been made apparent to the international community, judging from the long and meticulous work of the Working Group established in 2001 by the United Nations (UN) General Assembly (GA) 6th Committee for the purpose of drafting a comprehensive convention on international terrorism (UN Comprehensive Convention) ${ }^{3}$ and its persistence to soon conclude the drafting of such a convention. The extensive range of issues that the agreement on a definition for terrorism could address has been analysed elsewhere; ${ }^{4}$ for the purposes of this article, it is important to highlight that, since the adoption of the UN Security Council (SC) Resolution 1373 (Res. 1373), ${ }^{5}$ under which States are obliged to criminalise the financing of terrorism, suppress terrorist groups, deny refugee status to terrorists, prevent the movement of terrorists, bring terrorists to justice and establish terrorist acts as serious domestic crimes, the terms 'terrorism' and 'terrorist' are used in a way

1 It should be noted that international humanitarian law prohibits specific acts of terrorism committed in armed conflict and, as war crimes, a range of other acts of violence when committed against civilians or civilian objects. (Geneva Convention Relative to the Protection of Civilian Persons in Time of War (IV), 12 August 1949, entered into force 21 October 1950, 75 UNTS 287, Article 33; Protocol Additional to the Geneva Conventions of 12 August 1949, and relating to the Protection of Victims of International Armed Conflicts (adopted 8 June 1977, entered into force 7 December 1978) (Additional Protocol I) 1125 UNTS 3, Article 51(2); Protocol Additional to the Geneva Conventions of 12 August 1949, and relating to the Protection of Victims of Non-International Armed Conflicts (adopted 8 June 1977, entered into force 7 December 1978) 1125 UNTs 6o9, Article 4(2). See also International Committee of the Red Cross, The applicability of IHL to terrorism and counterterrorism, Report, 1 October 2015. Retrieved 24 March 2019, https://www.icrc.org/en/document/applicability-ihl-terrorism-and-counterterrorism)

2 For a discussion on defining and prosecuting terrorism before the International Criminal Court see I. Braber, 'Terrorism as a new generation transnational crime: prosecuting terrorism at the International Criminal Court', in H. van der Wilt and C. Paulussen (eds), Legal Responses to Transnational and International Crimes: Towards an Integrative Approach, Edward Elgar Publishing, Cheltenham, 2017, pp. 92-106.

3 UNGa 6th Committee (56th Session), 'Report of the Working Group on Measures to Eliminate International Terrorism', UN Doc A/C.6/56/L.9, 29 October 2001, para. 2.

4 S. Margariti, Defining International Terrorism, Between State Sovereignty and Cosmopolitanism, T.M.C. Asser Press, The Hague, 2017.

5 UNSC (2001) Resolution 1373, UN Doc. S/RES/1373. 
that creates international obligations and therefore, it needs an international definition for reasons of clarity. The assumption that national definitions and domestic counter-terrorist legislation are solid and operative to address international standards does not suffice and has often been proved erroneous. The work of the Counter-Terrorism Committee (CTC), established by Res. 1373 with the purpose to monitor States on its implementation, revealed the inadequacies of domestic counter-terrorism legislation and the arbitrary categorisation of a variety of national security or public order offences as terrorist. ${ }^{6}$ Res. 1373 did not define terrorism and therefore, the question of who qualifies as terrorist and what constitutes a terrorist act remains premised on each individual State's understanding.

The reports of the UN High Commissioner for Human Rights are revealing with respect to how counter-terrorism measures directly threaten human rights. State practice has shown that the measures taken by States as a response to security threats are not human-rights compliant, in the sense of being specific, necessary, effective and proportionate, also for reasons relating to the use of broad and imprecise definitions of what constitutes a terrorist act. ${ }^{7}$ These definitions violate the principle of legality and leave room for arbitrary and discriminatory enforcement by State authorities. More critically, there are cases where the death penalty finds application to terrorism-related offences, even when they are formulated broadly and are inclusive of non-violent acts (such as participation in 'criminal gangs' or 'terrorist groups'), ${ }^{8}$ violating thus Article 6 of the International Covenant on Civil and Political Rights (ICCPR). ${ }^{9}$ Also, some States might seek to avoid triggering criminal proceedings against suspects of terrorism but prefer to resort to administrative or other forms of detention or control orders. According to the Report of the Office of the UN High Commissioner for Human Rights in 2015, anti-terrorist legislation has

6 B. Saul, 'Defining Terrorism to Protect Human Rights' in Sydney Law School Research Paper No. 08/125, 2008, pp 1-17.

7 Report of the Office of the UN High Commissioner for Human Rights, Panel discussion on the effects of terrorism on the enjoyment by all persons of human rights and fundamental freedoms, A/HRC/30/64, 15 September 2015 (UN High Commissioner Report 2015), para 7.

8 Report of the Office of the UN High Commissioner for Human Rights, Negative Effects of Terrorism on the Enjoyment of all Human Rights and Fundamental Freedoms, A/HRC/34/30, 30 December 2016 (UN High Commissioner Report 2016), para. 22.

9 International Covenant on Civil and Political Rights (adopted 16 December 1966, entered into force 23 March 1976), 999 UNTS 171 (ICCPR). 
been also used to restrain otherwise legitimate activities and to target journalists, human rights defenders, minority groups and other individuals. ${ }^{10}$

However, it would be unfair to state that there have never been serious efforts to define terrorism. Besides the work of the Working Group of the 6th Committee, ${ }^{11}$ definitions -or definitional approaches someone might say- can be found in SC and GA resolutions, ${ }^{12}$ international and regional treaties ${ }^{13}$ and more recently, the jurisprudence of the Special Tribunal for Lebanon. ${ }^{14}$ The lengthy and laborious GA discussions in the context of the 6th Committee

10 UN High Commissioner Report 2015, above n. 7, para 7. See also the interview of Ambassador Michael Kozak, Head of the United States delegation to the Human Dimension Implementation Meeting in Security and Human Rights Monitor, Linking human rights to lasting security and cooperation, 17 September 2018. Retrieved 26 March 2019, https:// www.shrmonitor.org/osce-hdim-michael-kozak/.

11 Also, in an annual report submitted to the Human Rights Council by Martin Scheinin, the Special Rapporteur on the promotion and protection of human rights and fundamental freedoms while countering terrorism, a model definition of terrorism was proposed, beyond which, it was argued, would be problematic to go from a human rights perspective (see Report of the Special Rapporteur on the promotion and protection of human rights and fundamental freedoms while countering terrorism, Martin Scheinin, Ten areas of best practices in countering terrorism, A/HRC/16/51, 22 December 2010, para. 28). UNSC (2004) Resolution 1566, UN Doc. S/RES/1566, although not expressly referring to a definition for terrorism, sets a frame about which acts are unjustifiable under any circumstances. See also UNGA (1994) Declaration on Measures to Eliminate International Terrorism, UN Doc. A/REs/49/6o, para 3 .

13 See indicatively, International Convention for the Suppression of Financing of Terrorism, (adopted 9 December 1999, entered into force 10 April 2002) 2178 UNTS 197, Articles 2 (1a) (prohibiting acts constituting offences under nine anti-terrorist treaties) and $2(\mathrm{lb})$ (acts whose funding is prohibited) (Terrorism Financing Convention); Arab Convention for the Suppression of Terrorism (adopted 22 April 1998, entered into force 7 May 1999), Article 2; Organization of the Islamic Conference, Convention of the Organisation of the Islamic Conference on Combating International Terrorism, 1 July 1999, Annex to Resolution No: 59/26-P, Article 1 (2); Organization of African Unity (OAU), OAU Convention on the Prevention and Combating of Terrorism, 14 June 1999, Article 1(3). For a detailed list of international instruments that relate to terrorism see United Nations, International Instruments related to the Prevention and Suppression of International Terrorism, United Nations publication Sales No. E.08.V.2, New York 2008. Retrieved 24 March 2019, https:// www.unodc.org/documents/terrorism/Publications/Int_Instruments_Prevention_and_ Suppression_Int_Terrorism/Publication_-_English_-_08-25503_text.pdf)

14 Interlocutory Decision on the Applicable Law: Terrorism, Conspiracy, Homicide, Perpetration, Cumulative Charging, STL-11-01/I, 16 February 2011, paras 83-85. 
have demonstrated that the most contentious issues so far about defining terrorism focus more on the question of who can qualify as terrorist rather than on what terrorism actually is. Finally, despite the affirmations by State representatives that the lack of a definition for the purposes of the UN Comprehensive Convention is an impediment to the development of the law in the field and the expressions of commitment to resolve any issues, no agreement has as yet been reached. As of December 2018, the Chair of the Working Group recommended that the 6th Committee at the 74th session of the GA (OctoberNovember 2019) should establish a working group with the purpose to finalise the process on the UN Comprehensive Convention. ${ }^{15}$ The extent to which the work of the next session is going to be fruitful remains to be seen.

To this end, this article will first analyse how the very legal framework under which counter-terrorism legislation operates, namely transnational law, has sidestepped thus far the formulation of an international definition for terrorism, as it has mainly relied on the premises of domestic counter-terrorism legislation and definitions and has little to offer regarding human rights protection. This overreliance on domestic definitions for terrorism, the latter being extensively diverse among States, equals to overreliance on domestic human rights safeguards in the event of human rights violations in a counter-terrorism context. Therefore, it is precisely this overreliance on domestic laws and applicable definitions of terrorism, which leaves room for various human rights violations in the name of fighting terrorism.

Secondly, the article will turn to how States applied the counter-terrorism measures dictated by the SC resolutions and particularly, Res. 1373. State counter-terrorism laws adopted after $9 / 11$ reveal that not only terrorism is understood differently according to each State's interests but also that counterterrorism is used as a tool and pretext against what each State perceives as 'threat' in a dangerously widened manner, jeopardising rights such as freedom of expression, assembly and speech and sometimes even the right to life. Finally, the article will be complemented by an account of the steps taken by the UN bodies, such as the SC and the GA in their attempt to tackle the human rights issues emerged by States' counter-terrorism policies and how the work of the 6th Committee, if finalised, will contribute to a fuller protection of human rights in the context of countering terrorism.

15 UNGA Sixth Committee, Summary record of the 33rd meeting, A/C.6/73/SR.33, 6 December 2018. 


\section{Transnational Law and the Perpetuation of an 'undefined' Terrorism}

The absence of an international definition for terrorism is, to some extent, due to the modus operandi of the regime of transnational law under which counter-terrorism operates. According to Jessup, ${ }^{16}$ transnational law regulates transboundary actions, which, when of a legal kind, may have both 'international and national elements that do not fit within the traditional divisions'.17 According to Boister, ${ }^{18}$ transnational crimes are crimes that have actual or potential transboundary effects. The system of transnational law designed to address international terrorism as a transnational crime is comprised mainly of the international treaties relating to terrorist offences - called 'suppression conventions'19- and SC measures found in SC resolutions, but also, of the regional anti-terrorist conventions and, in the future, of the UN Comprehensive Convention. The suppression conventions, being the most popular and widely

16 P. Jessup, Transnational Law, Yale University Press, New Haven CT, 1956.

17 N. Boister, 'Transnational Criminal Law?' in European Journal of International Law, 2003, vol. 14, no. 5, pp 953-976.

18 Ibid, p. 955. For a detailed analysis of the nature and context of transnational law see N. Boister and R.J. Currie (eds.), Routledge Handbook of Transnational Criminal Law, Routledge, Oxon, 2015.

19 As anti-terrorist or 'suppression' conventions are considered the conventions that oblige States to criminalise particular conducts relating to terrorism, eg Convention for the Suppression of Unlawful Seizure of Aircraft (entered into force 14 October 1971) 860 UNTS 105; Convention for the Suppression of Unlawful Acts against the Safety of Civil Aviation (entered into force 26 January 1973) 974 UnTS 177; Convention on the Prevention and Punishment of Crimes Against Internationally Protected Persons (entered into force 20 February 1977) 1035 UNTS 167; International Convention Against the Taking of Hostages (entered into force 3 June 1983) 1316 UnTS 205; Convention on the Physical Protection of Nuclear Material (entered into force 8 February 1987) 1456 UnTs 246; Protocol for the Suppression of Unlawful Acts of Violence at Airports Serving International Civil Aviation, Supplementary to the Convention for the Suppression of Unlawful Acts Against the Safety of Civil Aviation (entered into force 6 August 1989) 1589 UnTs 474; Convention for the Suppression of Unlawful Acts against the Safety of Maritime Navigation (entered into force 1 March 1992) 1678 UNTS 201; Protocol for the Suppression of Unlawful Acts against the Safety of Fixed Platforms located on the Continental Shelf (entered into force 1 March 1992) 1678 UnTS 304; Terrorism Financing Convention, above n. 13; International Convention for the Suppression of Terrorist Bombings (entered into force 23 March 2001) 2149 UNTS 256 (Terrorist Bombings Convention); International Convention for the Suppression of Acts of Nuclear Terrorism (adopted on 13 April 2005, entered into force 7 July 2007) UN Doc A/REs/59/290.88. 
accepted mechanism of countering terrorism among States, provide for the indirect suppression, under international law, of certain terrorist offences carried out by non-State actors, through domestic criminalisation and prosecution. ${ }^{20}$ It will be shown below how this system has side-stepped, at least until now, the issue of agreeing on an international definition of terrorism, encouraging the application of disparate and often rights-violating national definitions. The mere fact that the UN Comprehensive Convention has taken so long to be finalised is indicative of the complications that a consensus on a definition for terrorism brings along when this consensus has to be achieved in a way that should accommodate all individual, and sometimes conflicting, States' interests in the field. ${ }^{21}$

'Indirect suppression',22 contrary to a direct suppression which is the case with international crimes giving rise to individual criminal responsibility under international criminal law, essentially means that the suppression conventions oblige States to criminalise (but do not criminalise per se) a list of acts that relate to terrorism (but do not constitute terrorism per se under these conventions). Most of these conventions, with the exception of the International Convention for the Suppression of Financing of Terrorism (Terrorism Financing Convention), the International Convention for the Suppression of Terrorist Bombings (Terrorist Bombings Convention) and the International Convention for the Suppression of Acts of Nuclear Terrorism, ${ }^{23}$ refrain from the use of terms such as 'terrorism' or 'terrorist'. ${ }^{44}$ But even when they do not, these conventions still overlook any particular terrorist elements in the definitions of these offences, failing thus to capture the distinctively wrongful character of terrorism. Practically, this leads to the resort to domestic counter-terrorist

$20 \quad$ N. Boister 2003, p. 955.

21 It is also interesting to note that, when the SC drafted Res. 1373, it deliberately circumvented the debates on an international definition on terrorism by allowing States' discretion in implementing the Resolution under their own domestic criminal definitions. See B. Saul, 'Terrorism as a Transnational Crime' in Legal Studies Research Paper No. 14/o6, January 2014, pp. 1-17.

22 Bassiouni argued that this indirect application has two serious risks: in substantive terms, the violation of the principle of legality through insufficient notice of proscription and penalty and, in procedural terms, the lack of human rights safeguards 'for those individuals who are the objects of...co-operative undertakings between states.' (M.C. Bassiouni, 'An Appraisal of the Growth and Developing Trends of International Criminal Law' in Revue Internationale de Droit Pénal, 1974, vol. 45, pp 405-433.)

23 Terrorism Financing Convention, above n. 13; Terrorist Bombings Convention, above n. 19; International Convention for the Suppression of Acts of Nuclear Terrorism, above n. 19.

24 B. Saul, 'Terrorism as a Transnational Crime' 2014, p. 4. 
laws and definitions and to the predominance of State sovereignty priorities in the field, often at the expense of human rights values. In sum, the inconsistencies of national definitions with respect to State human rights obligations entail the formulation of vague and discriminatory definitions (eg against minorities), the formulation of definitions in a way that suits political purposes or that camouflages violations of fundamental civil and political rights. ${ }^{25}$

This overreliance on domestic law also reveals some doctrinal weaknesses of transnational law as a system to suppress transnational crimes: the principle of legality requires that the same general principles, procedures and penalties should apply in any State with jurisdiction over a transnational offence. ${ }^{26}$ This, however, is not the case, with the result of having different domestic offences covering the same transnational conduct. The suppression conventions operate with the assumption that States have fully developed domestic criminal justice systems, in conformity with general international law principles (and possibly human rights safeguards), whereas, in fact, States are unwilling to harmonise their domestic penal systems more than necessary. ${ }^{27}$ What is more, the suppression conventions, being a product of an international order dominated by few powerful States, ${ }^{28}$ often reflect the ideas held by these influential States of how criminal law and punishment should be. This multi-State application of transnational law with respect to terrorist offences leads to massive variations in its implementation, ${ }^{29}$ resulting in violations of criminal law principles that should be in place in order to safeguard respect for fundamental human rights. It should be noted however that the adoption of the UN Comprehensive Convention, if achieved, might not escape from these weaknesses that are inherent when multilateral treaty negotiations take place; still, it cannot be overlooked that an international definition might constrain the adoption of 'more draconian national definitions in the future. ${ }^{30}$ As terrorism is a crime whose nature is constantly evolving, it is hoped that the UN Comprehensive Convention might provide a legal boundary not only for national definitions of terrorism - at least for those States that will become parties to the Convention- but also for any future SC Resolutions and international instruments to be adopted in a counter-terrorism context.

\footnotetext{
25 Ibid, p. 10.

26 N. Boister 2003, p. 955 .

27 Ibid, p. 958.

28 Ibid, p. 956.

29 Ibid, p. 958.

30 B. Saul, 'Three Reasons for Defining and Criminalizing Terrorism' 2014. Retrieved 17 June 2019, http://www.esil-sedi.eu/sites/default/files/Saul_o.PDF.
} 
At this point, it should be noted that variations in domestic laws are not exclusively manifest in the current instance where terrorist offences are suppressed as transnational offences and not as international crimes stricto sensu. Even in the case of terrorism rising up to an international crime proper, there might still be variations in domestic criminal definitions and procedure. As has already happened with the International Criminal Court (ICC) and the international crime definitions enshrined therein, States Parties have followed different approaches regarding the adoption of these definitions into their domestic criminal codes, varying from a verbatim adoption of the Article 5 of the Rome Statute - which enumerates the crimes under the jurisdiction of the ICC- ${ }^{31}$ to adopting narrower definitions ${ }^{32}$ or definitions taken by international law instruments other than the Rome Statute. ${ }^{33}$ However, contrary to the case of international crimes under the jurisdiction of the ICC or general international law, it is the variations in the domestic implementation of international counter-terrorism instruments that have caused an adverse effect on the enjoyment of human rights by encouraging the abusive use of terrorism definitions and counter-terrorism measures. Having that said, it is not the plurality of differentiated national legal traditions per se the reason why the suppression conventions on counter-terrorism have proven so far incapable of protecting human rights but the lack of clearer boundaries of legitimacy within which counter-terrorism can operate.

Turning to the question of what protection is afforded to human rights within the suppression conventions, the answer is little. ${ }^{34}$ Article 14 of the Terrorist

31 UN General Assembly, Rome Statute of the International Criminal Court (last amended 2010), 17 July 1998. Article 5 provides for the crimes under the jurisdiction of the ICC, namely genocide, crimes against humanity, war crimes and the crime of aggression. The UK adopted verbatim the Article 5 definitions under the UK International Criminal Court Act 2001, c17.

32 Under the Swiss Penal Code, provisions concerning the crime of genocide and the responsibility of senior officials are narrower than in the Rome Statute (Swiss Criminal Code, 21 December 1937, Article 259(1bis) on genocide and Article $264 \mathrm{k}(1)$ on superior responsibility).

33 The 2001 Law on the establishment of the Extraordinary Chambers of Cambodia, a hybrid international court, reproduces in part the provisions of the Rome Statute while it includes some formulations for crimes against humanity taken by the Statute of the International Criminal Tribunal for Rwanda, some acts of crimes against humanity were omitted and some others were only mentioned by reference and without definitions.

34 N. Boister 2003, p. 959. See also N. Boister, 'Human Rights Protections in the Suppression Conventions', in Human Rights Law Review, 2002, vol. 2, pp 199-227; R. Currie, 'The Protection of Human Rights in the Suppression of Transnational Crime', in N. Boister and R. Currie (eds.) 2015 . 
Bombings Convention and Article 17 of the Terrorism Financing Convention provide for the fair treatment of any person taken into custody 'including enjoyment of all rights and guarantees in conformity with the law of the State in the territory of which that person is present and applicable provisions of international law, including international law of human rights. ${ }^{35}$ However, according to Currie, this provision is symbolic and/or political as the details of the protection afforded under the said conventions depend on each State's individual human rights framework and on international human rights law instruments that States are (or are not) already bound to. ${ }^{36}$ Since the suppression conventions operate on the basis of domestic criminalisation and prosecution, they also rely on domestic human rights safeguards. Thus, any human rights issues that might arise are addressed at the national level reactively and not proactively. ${ }^{37}$ This practically means that human rights protection under a suppression convention will depend on factors such as adequate human rights provisions into domestic law, adherence to relevant international human rights treaties or even whether ' $[\mathrm{a}]$ state accepts that older human rights treaty obligations trump [the] application of a newer obligation under a suppression convention. ${ }^{38}$ De Londras is correct to wonder whether transnational law is 'effectively limited by fundamental legal principles, such as human rights, legality and proportionality'39 given that its enforcement might threaten human rights even outside a counter-terrorism context. ${ }^{40}$ As a result, it seems that the transnational legal sphere has developed in a way that permits States to create for themselves international obligations that may otherwise clash with other sets of international obligations assumed in a human rights context.

Last but not least, there is also another aspect which directly links the formulation of a definition for international terrorism with human rights violations. Up to date, the suppression conventions create obligations for States to criminalise terrorist offences carried out by non-State actors only, be it private natural persons, or juridical persons such as companies, or even State officials

35 Terrorist Bombings Convention, above n. 19, Article 14; Terrorism Financing Convention, above n. 13, Article 17.

36 R. Currie 2015, p. 13.

$37 \quad$ N. Boister 2003, p. 959 .

38 N. Boister, An Introduction to Transnational Criminal Law, oup, 2nd Edn, Oxford, 2018, p.41.

39 F. de Londras, 'Politicisation, Law and Rights in the Transnational Counter-Terrorism Space: Indications from the Regulation of Foreign Terrorist Fighters', in ERIS - European Review of International Studies, 2018, vol. 3, pp 115-138.

$40 \quad$ N. Boister 2018, p. 41. 
acting however in their private capacity (such as the police acting unlawfully). ${ }^{41}$ Even the Coordinator's Proposal of 2013 includes a 'carve-out' from the scope of the convention of the military forces of a State in time of peace. ${ }^{42}$ Any aspects of State terrorism, when manifested, would be addressed by other applicable fields of law, such as the UN Charter, international humanitarian law (IHL), international criminal law or the law on State responsibility for internationally wrongful acts, which cover State obligations when offences are committed by State agents. ${ }^{43}$ As such, States are only rarely condemned as terrorist. ${ }^{44}$ The impression that terrorism is committed by non-State actors only, reinforced by the suppression conventions and by States' inability to formulate an international definition for terrorism mainly for reasons related to the question of who can qualify as terrorist, leads to the assumption that terrorism is only used against a State and not by State authorities or agents against individuals or sub-national groups. It seems that the suppression conventions enhance State protection against accusations of using terrorism. However, under international human rights law, human rights are enjoyed vis-à-vis the State, meaning that if human rights are violated by a State through methods of terrorism, then these rights are not and cannot be guaranteed by any suppression convention. In an international human rights law context, terrorism can only violate human rights if practiced by States and not by non-State actors; ${ }^{45}$ however, in the transnational legal sphere, only terrorism practiced by non-State actors is regulated. In our context, this practically means that whenever individuals are labelled as terrorists according to domestic counter-terrorism legislation and are treated as such, then States can always use the pretext of counter-terrorism or national security as a cover-up in order to enforce rights-violating measures against them.

It is obvious from the above that the regime of the suppression conventions lacks in ability to provide essential human rights safeguards for those who are the objects of "cooperative undertakings between states" 46 but also for those that become victims of State-enforced or supported terrorism. In practice, this

\footnotetext{
$41 \quad$ N. Boister 2018, p. 6.

42 UNGA, Report of the Ad Hoc Committee established by Unga Res 51/210 of 17 December 1996, A/68/37, 8-12 April 2013,para 24 (UNGA Report 2013).

43 Ibid. See also N. Singh, 'The United Nations' Efforts at Combatting International Terrorism', in FICHL Policy Brief Series, 2017, No. 81, p. 4.

44 S. Zeidan, 'Desperately Seeking Definition: The International Community's Quest for Identifying the Specter of Terrorism' in Cornell International Law Journal, 2003-2004, vol. 36, pp 491-496.

45 B. Saul 2008, p. 3.

46 M.C. Bassiouni 1974.
} 
is also verified by how States have implemented their obligations under this regime and the relevant SC resolutions. It is common knowledge that domestic counter-terrorism laws and practice are often antithetical to human rights protection, either due to lack of scrutiny before their adoption or due to their deliberate instrumentality with the purpose of targeting any dissident voices or groups. The following part will show, through older and more recent examples of States' counter-terrorism legislation and domestic terrorism definitions, how fundamental human rights, such as freedom of expression, assembly and speech as well as the right to life, are often at stake in the fight against terrorism.

\section{Counter-terrorism Law and the Perpetuation of an Ill-defined Terrorism}

Counter-terrorism or special laws have not been directly associated with international terrorist threats until after $9 / 11,{ }^{47}$ and in particular, the adoption of UNSC Resolutions $1368^{48}$ and $1373,{ }^{49}$ which characterised the attacks as a threat to international peace and security. It has been argued by Birkhäuser that when the SC determines a situation as a threat to international peace and security, it practically declares a state of emergency, ${ }^{50}$ all the more because the said resolutions reaffirmed the right of individual or collective self-defence as a proper response to a terrorist attack. Under Res. 1373, States are also obliged

47 Long-lasting special laws, such as states of emergency, have been applied before with devastating consequences for human rights, on grounds, among others, of terrorism. Syria's emergency law, premised on the continuing war with Israel and terrorist threats, lasted from 1963 until 2011. Also, India has declared a state of emergency thrice, twice due to military crises and once -in $1975^{-}$due to what the then government considered to be a threat to security because of internal disturbances. (See R. Chaudhuri, 'India Has a Lesson for Trump: National Emergencies Are a Disaster for Democracy', in Foreign Policy, 21 February 2019. Retrieved 7 April 2019, https:/foreignpolicy.com/2019/02/21/ india-has-a-lesson-for-trump-national-emergencies-are-a-disaster-for-democracy/).

48 UNSC (2001) Resolution 1368, UN Doc. S/RES/1368.

49 Res. 1373, above n. 5 .

50 N. Birkhäuser, 'Sanctions of the Security Council against Individuals-Some Human Rights Problems'. Retrieved 7 April 2019, http://www.esil-sedi.org/english/pdf/Birkhauser.PDF. For an opposite view see I. Cameron, 'UN Targeted Sanctions, Legal Safeguards and the European Convention on Human Rights' in Nordic Journal of International Law, 2003, vol. 72 (2), pp. 159-214. 
to take several mandatory measures against 'terrorists'. ${ }^{1}$ Thus, and as it was also pointed out before, the definition of international terrorism ceases to be of a theoretical nature and starts acquiring an operative legal significance, ${ }^{52}$ for which no outer legal boundaries were set either by the SC resolutions or by the CTC.

It was at this call of the SC that various States reacted with the adoption of new or special legislation in a speedy way and without a proper a priori scrutiny, introducing broad definitions of terrorism and a wide range of new ancillary or inchoate terrorist offences. ${ }^{53}$ While there have been voices flagging the issue of human rights and IHL violations due to a lack of definition for terrorism, ${ }^{54}$ selective accusations became a standard practice among States such as Russia (calling Chechen rebels as terrorists when the Russian Constitutional Court had declared that Chechnya was an internal armed conflict regulated by IHL), China against Uighur separatists, India against militants in Kashmir, Chile against the Mapuche etc. ${ }^{55}$ It thus becomes obvious that counter-terrorism legislation has largely aimed at stifling political dissent and labelling political opponents and activists as terrorists. These aims however fundamentally depart from the need to prevent and address the type of terrorism suffered during $9 / 11$ and the need to establish the type of security required against terrorist threats of such a magnitude.

The situation in Chile serves as an indicative example in this respect. After 2001, prosecutions against the Mapuche indigenous group under the Chilean Anti-Terrorist Law seem to have been a standard practice of state authorities. In 2009, a Mapuche dissident was the first of many individuals that followed to be tried under the Chilean Anti-Terrorist Law - a legacy of the

$51 \quad$ Specifically, the text of Res. 1373 reads as such: 'Prevent and suppress the financing of terrorist acts; freeze (...) funds (...) of persons who commit, or attempt to commit, terrorist acts (...); deny safe haven to those who finance, plan, support, or commit terrorist acts (...); ensure that any person who participates in the financing, planning, preparation or perpetration of terrorist acts or in supporting terrorist acts is brought to justice and ensure that, (...), such terrorist acts are established as serious criminal offences in domestic laws (...); prevent the movement of terrorists or terrorist groups.'

$52 \quad$ B. Saul 2008, p. 6.

53 International Commission of Jurists, Assessing Damage, Urging Action: Report of the Eminent Jurists Panel on Terrorism, Counter-terrorism and Human Rights, Geneva, 2009, p. 124; Human Rights Council, Report of the UN High Commissioner for Human Rights on the protection of human rights and fundamental freedoms while countering terrorism, A/HRC/28/28, 19 December 2014, para. 27 (UN High Commissioner Report 2014).

54 B. Saul 2008, p. 7 .

55 Ibid. 
Pinochet regime- for alleged arson on a private estate and attack on a public defender's office; a case in which, according to the Observatory on the Rights of Indigenous People, "there [was] no organization for the purpose of sowing fear to the population". ${ }^{56}$ Apparently, the element of spreading terror to the public does not constitute part of the definition of terrorism under the AntiTerrorist Law of Chile, which was applied in such a broad way so as to cover what would otherwise be an ordinary crime. In fact, this was precisely the case before 2001, where prosecutions against the Mapuche did indeed take place, but were conducted on the basis of ordinary crimes, such as arson, theft and land grabbing. ${ }^{57}$ Therefore, convictions were hard to achieve due to procedural safeguards in place for the defendants. ${ }^{58}$ After 2001 however, under a modified Anti-Terrorist Law, the Chilean authorities have been able to implement different procedures for terrorist crimes than for ordinary crimes. These procedures entail lengthy pre-trial detention, increased sentences and even loss of citizenship. ${ }^{59}$ All these evince that the Chilean authorities, who have been targeting the Mapuche since the Pinochet dictatorship, have effectively used an antiterrorist legal framework to crush a minority indigenous group, who has been resisting for years to the appropriation of their ancestral lands by the Chilean State and forestry companies.

The story of the Mapuche group protesting to defend their land rights and being prosecuted as terrorist for this is sadly not the only example of misused and abused counter-terrorist legislation, based on vague and broad definitions. ${ }^{60}$ This type of State practices against minority groups or individual protesters has been characterised as State terrorism itself,, ${ }^{61}$ which gains legitimacy when put under the umbrella of 'fighting terrorism'. This being said, if the forthcoming UN Comprehensive Convention does not include State terrorism in its definition, then human rights violated by States resorting to

56 P. Sepulveda, CHILE: Gov't Unleashes Anti-Terror Law on Mapuche Activist, 23 February 2009. Retrieved 3 April 2019, http://www.ipsnews.net/2009/02/chile-govt-unleashes-antiterror-law-on-mapuche-activist/. See also E. Nagle, 'Terrorism and Universal Jurisdiction: Opening the Pandora's Box?', in Georgia State University Law Review, 2010-2011, vol. 27, pp 339-378.

57 N. Bialostozky, 'The Misuse of Terrorism Prosecution in Chile: The Need for Discrete Consideration of Minority and Indigenous Group Treatment in Rule of Law Analyses', in Northwestern Journal of International Human Rights, 2008, vol. 6, pp 81-103.

$5^{8} \quad$ Ibid, p. 83 .

59 Ibid, p. 84.

6o S. Cuffe, Anti-Terrorism Laws Increasingly Used to Target Indigenous Activists, 12 October 2018. Retrieved 3 April 2019, https://truthout.org/articles/anti-terrorism-laws-increasingly -used-to-target-indigenous-activists/.

61 S. Zeidan 2003-2004, p. 495. 
terrorist methods will remain in a vacuum. Without disregarding the complexities of including State terrorism in the UN definition, ${ }^{62}$ a definition taking no notice of State terrorism will unavoidably shift the focus -once more- to the perpetrator of a terrorist act rather than the act itself, will not contribute to the attenuation of politically motivated abuse of the term 'terrorist' and will miss the chance of creating a -hopefully- more effective stronghold against human rights violations being committed by States that resort to terrorist tactics.

It can be said that broad and imprecise domestic definitions may have an impact on almost all human rights, civil and political rights being the most common. Criminalisation of the freedom of expression and speech is frequently encountered when domestic definitions of terrorism include acts that "[insult] the reputation of the State or its positions", ${ }^{63}$ encourage, ${ }^{64}$ praise, glorify, justify or advocate ${ }^{65}$ terrorism, or when someone professes to belong to an organisation listed as terrorist, ${ }^{66}$ or criticise "the official ideology of a State". 67 While the aim of this article is not to elaborate further on the extent to which each one of these formulations clashes with the limitation clauses as found in international human rights law instruments, it should be noted that these definitions were not adopted in the context of a state of emergency - at

62 B. Weißer, 'Transnational Organised Crime and Terrorism', in P. Hauck and S. Peterke (eds.), International Law and Transnational Organised Crime, oup, Oxford, 2016, pp 84-103. Weißer argues that there are two types of State terrorism: one including acts of violence committed by State authorities against opponents and another including State support (financial or logistic) to terrorist groups that operate domestically or abroad. She further argues that the first type of State terrorism is addressed by $\mathrm{IHL}$, as a crime against humanity or a war crime in case of armed conflict, and the second one can be covered by international criminal law, as the crime of aggression, or by the international law on the use of force. (B. Weißer 2016, pp 95-96).

63 UN High Commissioner Report 2014, above n. 53, para. 22.

64 Ibid. See also Human Rights Committee, General Comment 34, CCPR/C/GC/34, 12 September 2011, para. 46, which, referring to anti-terrorist legislation of the UK and the Russian Federation, states that "such offences [as encouraging terrorism] should be clearly defined to ensure that they do not lead to unnecessary or disproportionate interference with freedom of expression".

65 Australia, Counter-Terrorism Legislation Amendment (Foreign Fighters) Act, 2014 [Cwlth] s. 61.

66 UK Terrorism Act 2000, s. 11.

67 In 1993, the Turkish courts issued a decision which held that an academic publication criticising the official ideology of Turkey fell within the category of publications covered by the Turkish Prevention of Terrorism Act and constituted separatist propaganda which undermined the territorial integrity of the State (in A. Salinas de Frias, Counter-Terrorism and human rights in the case law of the European Court of Human Rights, Council of Europe Publishing, Strasbourg 2012, p. 117). 
least officially declared-and have been considered as potentially incompatible with Article 19 (3) of the $\mathrm{ICCPR}^{68}$ and as imposing an unjustified limitation on the freedom of expression since they might entail criminalisation of any discourse critical to a government or its policies. ${ }^{69}$ Focusing on legislation adopted after $9 / 11$, and despite the existence of anti-terrorism legislation which was in place to address Northern Irish terrorism, the UK adopted in 2001 the Anti-Terrorism, Crime and Security Act 2001, which prioritised intelligence and executive powers over a criminal approach to terrorism. ${ }^{70}$ Also, the Terrorism Act 2000, which was revised in 2006 after the 2005 London bombings in order to include a wide range of preparatory offences, ${ }^{71}$ provides that membership to an organisation proscribed as terrorist is an offence, membership not being limited to belonging but also extending to professing to belong to such an organisation. ${ }^{72}$ Even the House of Lords in Sheldrake $v$ Director of Public Prosecutions $^{73}$ found the offence to be extremely broad, with the risk of capturing persons not 'blameworthy of any criminal conduct. ${ }^{74}$ Moreover, given the fact that the UK definition for terrorism does not provide any exception for legitimate struggles or resistance against oppressive regimes, offences such as encouragement or glorification of terrorism might as well extend to situations of a person encouraging or glorifying the overthrow of oppressive regimes or acts of resistance.

68 ICCPR, above n. 9, Art. 19(3): "the exercise of the rights provided for in paragraph 2 of this article carries with it special duties and responsibilities. It may therefore be subject to certain restrictions, but these shall only be such as are provided by law and are necessary: (a) For respect of the rights or reputations of others; (b) For the protection of national security or of public order (ordre public), or of public health or morals."

69 UN High Commissioner Report 2014, above n. 53, para. 22. For an analysis of the status of human rights in states of emergency in the context of countering terrorism, see Human Rights Council, Report of the Special Rapporteur on the promotion and protection of human rights and fundamental freedoms while countering terrorism on the human rights challenge of states of emergency in the context of countering terrorism, A/HRC/37/52, 27 February 2018. For a detailed analysis and account of the European Court of Human Rights' case law on human rights and counter-terrorism, see A. Salinas de Frias 2012.

70 N. McGarrity and J. Blackbourn, 'Anti-Terrorism laws and human rights' in L. Weber, El. Fishwick and M. Marmo (eds.), Routledge International Handbook of Criminology and Human Rights, Routledge, Oxon, 2017.

71 Ibid.

72 UK Terrorism Act 2000, s. 11.

73 Sheldrake v Director of Public Prosecutions; Attorney's General Reference (No 4 of 2002) [2004] UKHL 43, para. 48.

74 N. McGarrity and J. Blackbourn 2017. 
More regrettably, overbroad definitions can even put at serious risk the right to life. In a criminal law context, criminal law (including counterterrorism legislation) shall be precise, the criminal offences being clearly defined and the penalty clearly prescribed. Since this is not yet the case regarding terrorism, due to the lack of an international definition, the risk of arbitrary arrests, detentions and punishments (irreversible ones if the death penalty is applicable) is high. As mentioned earlier, there are several States (Afghanistan, Bahrain, Congo, Egypt, Iraq (Kurdistan), Mali, Mauritania, Qatar, Sudan, UAE, Vietnam $)^{75}$ that still enforce the death penalty for terrorism-related offences, even if these are non-violent and entail acts such as participation in 'criminal gangs' or 'terrorist groups.' ${ }^{76}$ Also, domestic definitions of terrorism might endanger the right to life when they include acts committed 'against the security of the State' (Libya) or other acts that do not result in death but in taking property or damaging public resources (Indonesia). ${ }^{77}$ More recently, the Egyptian authorities executed nine people for the assassination of the country's Prosecutor-General in 2015. After the 2013 coup, the Egyptian authorities have systematically targeted the Muslim Brotherhood of ex-President Morsi, who was deposed in the coup. ${ }^{78}$ The said Brotherhood has been categorised as a terrorist organisation while hundreds of its supporters have been sentenced to death since the military-supported President Sisi came to power. ${ }^{79}$ Furthermore, with 'national security' as justification and in furtherance of its counterterrorism strategy, Egypt extended its terror list by adding 145 people, including two journalists, who were presumably supportive of the Muslim Brotherhood and were accused by the local media of 'promoting terrorism and attempting to destabilise the country'. ${ }^{80}$ All these examples of ill-defined 'terrorisms' evince once more the urgency of formulating an international definition and remind us how much is at stake for human rights if the international community keeps failing to do so.

75 World Coalition Against the Death Penalty, The Death Penalty for Terrorism, September 2016 (World Coalition contribution). Retrieved 19 April 2019, https://www.pgaction.org/ pdf/campaigns/death-penalty-for-terrorism.pdf.

76 UN High Commissioner Report 2016, above n. 8.

77 World Coalition contribution, above n.75.

78 TRT World, 'Egypt executes nine for 2015 murder of prosecutor general', 20 February 2019. Retrieved 19 April 2019, https://www.trtworld.com/middle-east/egypt-executes-nine-for -2015-murder-of-prosecutor-general-24315.

79 Ibid.

8o Middle East Monitor, 'Egypt adds 145 people, including journalists, to terror list', 27 March 2019. Retrieved 19 April 2019, https://www.middleeastmonitor.com/20190327egypt-adds-145-people-including-journalists-to-terror-list/. 
Having examined how the transnational law regime is inadequate to firmly protect human rights and how domestic definitions of terrorism can endanger this protection, it is worth shedding some light into the stance of the UN and its counter-terrorism organs towards this rights-violating atmosphere triggered by, among other factors, the lack of an international definition for terrorism. The SC and the GA have apparently taken notice of the backlash that counter-terrorism legislation has caused against human rights and have created a number of bodies with the aim to address such situations. Although the acknowledgment of this issue is a first step, the UN efforts in this respect seem to be deficient due to the failure of mainstreaming human rights principles across the work of all the UN bodies working on counter-terrorism but also due to the standstill of the work of the 6th Committee in the drafting of the UN Comprehensive Convention.

Starting with the SC, which was the UN body that dominated the response and the UN counter-terrorism strategy to be followed after the 9/11 attacks, Res. 1373 established the CтC with the purpose to monitor and supervise States on the implementation of the measures prescribed therein. As was mentioned above, the стс did not define terrorism, acknowledging the variations in the definitions of domestic legal systems. ${ }^{81}$ However, this automatically meant that the СтC also acknowledged that 'terrorism can be combatted without agreement on its criminality in all situations. ${ }^{82}$ Instead of encouraging narrow and precise national definitions, it supported that national domestic laws should be widened in order to cover international terrorism..$^{83}$ Moreover, through the evaluation of States' reports on the implementation of Res. 1373, the СтC sought to achieve results in the following thematic areas: the establishment of a legal anti-terrorist framework -including urging States to sign the suppression conventions- the fight against terrorism financing, the maintenance of effective border controls and, much later, the protection of human rights. ${ }^{84}$ It was with the creation of the CтC Executive Directorate (CTED) in 2004 and the

\footnotetext{
81 B. Saul 2008, p. 6.

82 Ibid.

83 Ibid.

84 L.M. Hinojosa-Martinez, 'A critical assessment of the implementation of Security Council Resolution 1373' in B. Saul (ed.), Research Handbook on International Law and Terrorism, Edward Elgar Publishing, Cheltenham, 2014, pp. 626-650.
} 
inclusion of a senior human rights officer in its ranks that the CTC started working together with the UN human rights bodies on the promotion and protection of human rights while countering terrorism. The CTED has indeed identified as areas of concern the abusive enactment of emergency and special laws to presumed terrorists and the use of overly broad definitions of terrorism or of incitement to terrorism as an excuse to limit freedom of expression and other civil rights. Even so, the CTC still views that the respect for human rights is more of 'a wanted complement of counter-terrorist policies rather than an essential instrument for the ethical defeat of terrorism' 85 and its focus remains first and foremost the enforcement of the SC counter-terrorism measures. In this respect, it cannot be expected from a primarily executive organ, such as the CTED, with only a limited human rights element in its mandate, to be at the forefront of human rights protection in countering terrorism, especially when its assessments on State implementation of counter-terrorism measures are not made public. ${ }^{86}$

The adoption of Res. 1373 -with its 'all necessary steps' approach and the invocation of the right to self-defence- and the early years of the CTC's work left human rights in a vacuum during the early days of counter-terrorism and demonstrated the SC's will to dictate the UN's response after the $9 / 11$ attacks. ${ }^{87}$ However, the GA led several efforts to form a human-rights protecting framework after the repercussions of special or emergency legislation on the enjoyment of human rights. In 2005, the Counter-Terrorism Implementation Task Force (CTITF) was established with the purpose of coordinating the counterterrorism efforts in the UN system and it has engaged in capacity-building initiatives which have some human rights elements. ${ }^{88}$ It is mainly the Office of the High Commissioner for Human Rights that undertakes most of the human rights-related work of the CTIтF. ${ }^{89}$ Also, in 2014, the CTIT F issued a Basic Human Rights Reference Guide for member States, in order to assist them in the promotion of human rights in countering terrorism. ${ }^{90}$ These guidelines

$85 \quad$ Ibid, p. 639 .

86 Human Rights Council, Report of the Special Rapporteur on the promotion and protection of human rights and fundamental freedoms while countering terrorism, A/HRC/34/61, 21 February 2017 (HRC Report 2017), para. 60.

87 E. Rosand, 'UN Counterterrorism Reform: Now It's the Security Council's Turn', 15 September 2017. Retrieved 15 April 2019, https://theglobalobservatory.org/2017/og/ terrorism-countering-violent-extremism-guterres/.

88 HRC Report 2017, above n. 86, paras. 54 and 57.

89 Ibid, para. 56 .

90 Counter-Terrorism Implementation Task Force (Стіт), Basic Human Rights Reference Guide: Conformity of National Counter-Terrorism Legislation with International Human 
also meant to promote the United Nations Global Counter-Terrorism Strategy (Counter-Terrorism Strategy) ${ }^{91}$ and particularly its fourth pillar (human rights protection while countering terrorism), and were premised on the need for conformity between national counter-terrorism and international human rights law. Also, embedded within the CTITF is the UN Counter-Terrorism Centre (UNCTC), which develops, funds and implements counter-terrorism capacity-buildings projects. ${ }^{92}$ Finally, in early 2018, the Secretary-General Guterres signed the UN Global Counter-Terrorism Coordination Compact (Global Compact), ${ }^{93}$ replacing the CTITF coordination arrangement. The Global Compact aims at strengthening "a common action approach to coordination and coherence in the counter-terrorism and prevention of violent extremism work of the [UN] system" and at supporting Member States in implementing the Counter-Terrorism Strategy. ${ }^{94}$ It is also the largest coordination framework across the four pillars of the work of the UN: peace and security, sustainable development, human rights and humanitarian affairs. ${ }^{95}$

However, it remains true that none of these bodies has human rights at the forefront of its mandate. The CTITF, despite all its work, could not make human rights assessments on States to which it provides capacity-building assistance ${ }^{96}$ and the UNCTC focuses more on issues of security and enforcement. ${ }^{97}$

Rights Law, United Nations, New York, 2014. Among other things, these principles provide that counter-terrorism measures should comply with all State obligations under international law, included under international human rights law; that the principle of legality should be respected at all times and all national definitions for terrorism should be clear, precise and not overly broad; that counter-terrorism measures and the conduct of State agents should be consistent with international human rights law, refugee law and international humanitarian law if applicable; and that States are obliged to conduct investigations for allegations of human rights violations, including during counter-terrorism operations.

91 GA, The United Nations Global Counter-Terrorism Strategy, A/RES/6o/288, 2006.

$92 \quad$ HRC Report 2017, above n. 86, para. $5^{8}$.

93 United Nations Office of Counter-Terrorism, Coordination and coherence of the counter-terrorism efforts of the United Nations. Retrieved 11 June 2019, https://www.un.org/ counterterrorism/ctitf/en.

94 Report of the Secretary-General, Activities of the United Nations system in implementing the United Nations Global Counter-Terrorism Strategy, A/72/840, 20 April 2018, Annex III, para 9 .

95 United Nations Office for Counter-Terrorism Press Release, The United Nations is strengthening coordination to address terrorism, 6 December 2018. Retrieved 11 June 2019, https://www.un.org/counterterrorism/ctitf/sites/www.un.org.counterterrorism.ctitf/ files/201801206_Pressrelease_GlobalCompact.pdf.

$96 \quad$ HRC Report 2017, above n. 86, para. $5^{6}$.

$97 \quad$ Ibid, para. $5^{8}$. 
Moreover, the mandate of the Special Rapporteur, the only UN entity with a clear duty to promote and protect human rights while countering terrorism, is unusually broad, varying from country visits and reporting to the SC and GA, providing advisory services and technical assistance to States, exchanging information on alleged violations of human rights and working in cooperation with all relevant actors within the UN system. ${ }^{98}$ These wide-ranging responsibilities of the Special Rapporteur, together with the work of the other UN counter-terrorist bodies, result in an overlap of mandates and tasks, revealing thus the need of the UN to be seen to speak with one voice' ${ }^{\prime 99}$ on questions of human rights in the context of counter-terrorism.

It was for this purpose that in 2017, Secretary-General Guterres created the first-ever UN Office of Counter-Terrorism in order to enhance collaboration between the several UN bodies working on counterterrorism. ${ }^{100}$ However, it has been argued that even this considered-to-be major reform in the operation of the multiple UN counterterrorism agencies is not practically so deep in order to align the role of the UN bodies with the principles enshrined in the Global Counter-Terrorism Strategy, including the promotion of human rights in countering terrorism. ${ }^{101}$ In fact, the 2018 review of the Global Counter-Terrorism Strategy received a lot of criticism ${ }^{102}$ about failing to address, among other things, human rights abuses, the increased militarisation of counter-terrorism operations and the erosion of IHL in the name of combatting terrorism. ${ }^{103}$

Despite all these efforts undertaken to protect and promote human rights while countering terrorism, it seems that there is still a long way before human rights are mainstreamed into the work of the UN bodies with a mandate to address several aspects of counter-terrorism. There is still a step to be taken by the Working Group of the 6th Committee, which is the formulation of a UN definition of terrorism. Although the mandate of the Working Group and the substance of the UN Comprehensive Convention are not directly linked to human rights, the agreement on a universally accepted definition of

\footnotetext{
98 Ibid, paras. $49-50$.

99 Ibid, para. 54 .

$100 \quad$ E. Rosand 2017.

101 Ibid.

102 H. Megally, 'The UN Global Counter-Terrorism Strategy Review: Raised expectations, missed opportunities from the June 2018 review', Center on International Cooperation, August 2018. Retrieved 15 April 2019, https://cic.nyu.edu/publications/UN-Global-Counter -Terrorism-Strategy-Review; FIDH Press Release, 'Global Group of NGOs Deplore Lack of Attention to Human Rights in Latest Review of UN's Global Counterterrorism Strategy by UN Member States', 11 July 2018. Retrieved 15 April 2019, https://www.fidh.org/en/ global-group-of-ngos-deplore-lack-of-attention-to-human-rights-in.

103 Ibid.
} 
terrorism will enhance human rights protection both through the setting of some minimum legal standards on the legal concept of terrorism and through the delimitation of its scope of application.

Regarding the definition of terrorism per se, agreement has been reached on the list of offences covered by the UN Comprehensive Convention under its proposed Article 2. ${ }^{104}$ The main issue that arises in relation to human rights focuses mostly on the question of the applicability of I HL vis-à-vis the offences enumerated in Article 2, as these offences are not unlawful under I HL. Coupled with the fact that the UN Comprehensive Convention will not be applicable to acts committed within a single State, it is still a point of contention whether acts committed in a non-international armed conflict context will be covered and to what extent (taking also into account the considerable number of noninternational armed conflicts with an international dimension). ${ }^{105}$

In summary, the outstanding issues regarding the draft definition of terrorism under the proposal of the Coordinator of the Working Group of the 6th Committee ${ }^{106}$ revolve around two particular questions: the potential blurring between the exercise of the right to self-determination and terrorist acts and the inclusion of 'State terrorism.'107 Draft Article 3 (former Article 18) provides that the UN Comprehensive Convention will exempt from its scope ' $[t]$ he activities of armed forces during an armed conflict, as those terms are understood under international humanitarian law, which are governed by that law' and ' $t$ t] he activities undertaken by the military forces of a State in the exercise of their official duties, inasmuch as they are governed by other rules of international law'.108

Regarding the first exception, it has been suggested that, as it is formulated, it will not cover activities of armed resistance groups or 'unprivileged combatants' against a party to the conflict, namely groups which do not belong to a State's army and which are otherwise lawful under IHL. ${ }^{109}$ According to the Organisation of the Islamic Conference (OIC), the formulation of this

\footnotetext{
104 UNGA Report 2013, above n. 42, Annex I.

105 J. Pejic 'Armed Conflict and Terrorism' in Ana Maria Salinas de Frias, Katja Samuel and Nigel White (eds), Counter-Terrorism: International Law and Practice (ouP 2012) 171, p. 192-93.

106 UNGA, Report of the Ad Hoc Committee established by UnGA Res 51/210 of 17 December 1996, A/57/37, 28 January-1 February 2002 (Ad Hoc Committee Report 2002).

107 UNGA Sixth Committee, Summary record of the 33rd meeting, A/C.6/73/SR.33, 6 December 2018, para. 6 .

108 UNGA Report 2013, above n. 42, Annex II.

109 M. Hmoud, 'Negotiating the Draft Comprehensive Convention on International Terrorism' (2006) Journal of International Criminal Justice vol. 4, 1031-1043.
} 
provision as it stands in its draft form will potentially allow the labelling of armed groups other than State armed forces as terrorist, thereby IHL will not apply. An alternative suggestion coming from the oIC is to replace 'armed forces' with 'parties' so as not to exclude from the scope of the convention any armed groups fighting against occupation and to avoid their labelling as terrorists. ${ }^{110}$ However, the Report of the Ad Hoc Committee in 2013 argued that the term 'armed forces' was preferable, as it was well established under IHL while also covering activities of non-State actors, as long as certain conditions under that law are met. ${ }^{111}$ Besides, the term 'armed conflict' under IHL was understood as entailing situations of foreign occupation, something that leads to the conclusion that at least some of the armed forces in such a conflict would by implication be non-State armed groups. ${ }^{112}$ On the other hand, there were delegations that feared that behind the oIc's suggested term 'parties' was the intention to cover an array of actors, such as disorganised armed groups ${ }^{113}$ or civilians unaffiliated or loosely affiliated with such groups and who may commit isolated acts of violence. ${ }^{114}$ In any case, and in accord with the proposed preambular paragraph of the UN Comprehensive Convention on the reaffirmation of the right to self-determination, ${ }^{115}$ it should be noted that, although this right in the past focused more on fights 'against colonial domination, (...) alien occupation and against racist regimes, ${ }^{\prime 16}$ today it might be extended so as to include political struggles for greater democracy and human rights. ${ }^{117}$ While the right of self-determination is well-established under international law and it might seem unnecessary to reiterate it in the context of a convention on terrorism, this right has so far been protected under the UN Charter and IHL in the context of internal armed conflicts, and under the ICCPR as a political right, ${ }^{118}$ but nowhere self-determination has been related to and protected against States' abusive use of the term 'terrorism'. The example of the Mapuche

\footnotetext{
110 Ad Hoc Committee Report 2002, above n. 106, Annex IV.

111 UNGA Report 2013, above n. 42, para. 26.

112 Ibid.

113 J. Pejic 2012, p. 193

114 B. Saul, 'Terrorism, Counter-Terrorism and International Humanitarian Law', Legal Studies Research Paper No. 16/37, May 2016, pp 1-19.

115 UNGA, Proposal to facilitate discussion by the Friends of the Chairman of the Working Group on measures to eliminate international terrorism, A/C.6/6o/INF/2, 20 October 2005 .

116 Additional Protocol I, above n. 1, Article 1(4).

117 E. Chadwick, 'Terrorism and Self-determination' in B. Saul (ed.), Research Handbook on International Law and Terrorism, Edward Elgar Publishing, Cheltenham, 2014, pp. 298-314.

118 ICCPR, above n. 9 and International Covenant on Economic, Social and Cultural Rights 993 UNTS 3 (adopted 16 December 1966, entered into force 23 March 1976) Common Article 1.
} 
mentioned previously is indicative of a situation where a sub-national group fighting for its lands -even if it does not aim at the overthrow of the current government- is viewed and treated as terrorist with particularly aggravating consequences for its members. If the right to self-determination is now understood as covering political struggles and fights for greater democracy, then it should be protected not only in the context of an armed conflict (such as against colonialism) or as a political right, but also against any overlap with a definition of terrorism.

Regarding the second exception referring to the activities of the 'military forces of a State, in the exercise of their official duties', there is no specification of whether these activities are carried out in armed conflict or in peacetime, so it is understood that they can be carried out in both circumstances. However, the provision continues by stating that these activities are exempted 'inasmuch as they are governed by other rules of international law' -'by other rules' obviously referring to IHL applicable in armed conflict and to rules other than IHL applicable in peacetime. If 'inasmuch as' is to be understood as 'to the extent' these acts are governed by other rules of international law, ${ }^{119}$ it is hard to identify any cases where these acts cannot fall into the ambit of any other body of law, which might as well be emergency or special counter-terrorism legislation stemming from rules enshrined in SC Resolutions. Thus, the overall effect of this exception will be to generally exclude acts that will otherwise fall into the definition of terrorism of the UN Comprehensive Convention, when carried out by the military forces of a State. In an effort to include into its scope incidents of terrorist acts committed by military forces, the Organisation of the Islamic Conference made an alternative proposal to this formulation suggesting that 'the activities of the military forces of a State, in the exercise of their official duties' be exempted from the scope of the Convention, 'inasmuch as they are in conformity with international law.'120

A final point is worth making in this respect. Although it is hoped that, since the text of the UN Comprehensive Convention is the result of laborious multilateral treaty negotiations, most of the members of the UN will become parties to it, as is the case with the Terrorist Financing and the Terrorist Bombings Conventions, it should be born in mind that States will always seek to shield themselves against accusations that their armed forces resort to acts possibly falling into the concept of State terrorism. In 2016, in a Written Ministerial Statement, the then UK Secretary of State for Defence, Sir Michael Fallon stated that the UK government intends to derogate from the European Convention

119 M. Hmoud 2006, p. 1041.

120 Ad Hoc Committee Report 2002, above n. 106, Annex IV. 
on Human Rights with respect to UK military operations abroad in order to protect its armed forces from allegations of human rights violations. ${ }^{121}$ This proposal was initiated for reasons related, among others, to the protection of the armed forces from human rights claims 'that undermine their ability to do their jobs'122 and it has also been argued that such a proposal 'will allow the [UK] Government to get a head start on discrediting the work of the International Criminal Court where its prosecutor announced in December 2017 that there is a "reasonable basis to believe that [in Iraq] members of the UK armed forces committed war crimes within the jurisdiction of the court against persons in their custody". ${ }^{123}$ It becomes obvious from the above that, in the event of inclusion of any State terrorism aspect into the UN definition of terrorism, the path that many States will seek to follow, will be similar to that of the UK, either through derogations or non-ratification. Regardless of how much work is or will be put by the UN bodies into the mainstreaming of human rights in counter-terrorism measures and strategies, ultimately it is at the discretion of States whether human rights values will be instilled and applied into their domestic counter-terrorism legislation and whether they will agree to be bound by them.

\section{5}

\section{Conclusion}

In view of the human rights violations that currently take place in the context of counter-terrorism, this article aimed at demonstrating how agreeing upon an international definition for terrorism will contribute to some extent to a further enhancement of human rights protection in this context. It was argued that the system of the suppression conventions as a means to combat terrorism is fraught with problems in this respect, not the least because States will always seek to prioritise law enforcement over human rights, sometimes to

121 HC Hansard, cols 3-4WS, 10 October 2016. Retrieved 22 April 2019, https://hansard.parliament.uk/commons/2016-10 10/debates/1610102000014/MilitaryOperationsEuropean ConventionOnHumanRightsDerogation.

122 M. Fallon, 'Members of our armed forces were victims of a charismatic conman who exploited vulnerabilities in the legal system' in The Daily Mail, 10 February 2017. Retrieved 22 April 2019, https://www.dailymail.co.uk/news/article-4213576/Troops-victims-charismatic-conman.html.

123 M. Ammos, 'Abuse of the Constitution for Political Gain: The United Kingdom's Proposed Derogation from the European Convention on Human Rights', Paper delivered at IACLAIDC World Congress 2018 Workshop 2: Abuse of the Constitution in Times of Emergency, June 2018, pp. 1-24. Retrieved 22 April 2019, https://ssrn.com/abstract=3247744. 
the detriment of international legality. Several examples have been mentioned herein with respect to how States in practice interpret terrorism and counterterrorism and when this interpretation comes arbitrarily, what we end up with is a normalisation of human rights violations and in the most extreme cases, a perpetuation of violence. The UN has addressed this situation by establishing several bodies mandated with human rights-related tasks, however a holistic approach to human rights violations by the $\mathrm{UN}$ is still missing.

It is hoped that the work of the Working Group on the UN Comprehensive Convention will fill some gaps regarding the protection of rights. However, this is not to say that agreeing on an internationally accepted definition will automatically put an end to human rights abuses in this respect. It will only address (and perhaps only to an extent) some considered-to be controversial issues, which, when settled, will help delineating the boundaries of the concept of State terrorism and the relationship between the scope of the UN Comprehensive Convention and I HL. For human rights values to be instilled into the application of counter-terrorism legislation, the UN bodies should aim at working in a more customised manner with the States concerned, focusing on their individual domestic legal values and working on ways to adjust these values to universally accepted human rights standards. 